\title{
Ján Kollár avagy a szláv nemzet jó tulajdonságai?
}

\author{
Kiss Szemán Róbert
}

Eötvös Loránd Tudományegyetem, Budapest, Bölcsészettudományi Kar, Szláv Filológiai Tánszék, Múzeum krt.4/D,HU-1088Budapest, rkiss@centrum.cz

Študija opozarja na Kollárjevo parno pridigo, ki je imela velik vpliv na nacionalno zavest sodobnih slovanskih narodov. Kollár razpravlja o petih dobrih lastnosti slovanskih narodov: njihovi pobožnosti, marljivosti, veselosti, ljubezni do materinščine in popustljivosti do drugih narodov. Med možne prototipe te pridige sodi članek Jánosa Horvátha z naslovom $O$ verskem in moralnem stanju starih Madžarov v izdaji Tudományos Gyüjtemény iz leta 1817. Način prevzemanja lahko razumemo tudi kot ustvarjalno umetniško dejavnost, s katero je Kollár znatno reinterpretiral omenjene lastnosti in jih prenesel na slovanski narod.

This study calls attention to Kollár's two-part sermon which exerted a large influence on the national consciousness of the modern Slav nations. Kollár discusses five good qualities of the Slav nation: its godliness, diligence, cheerfulness, love of mother tongue, and forbearance towards other nations. Among the possible prototypes of this sermon are a paper by János Horváth, entitled "On the Religious and Moral Condition of the Hungarians" in the 1817 volume of Tudományos Gyujitemény. The manner of adoption can be seen as creative artistic activity, in the course of which Kollár significantly reinterpreted the qualities in question and applied them to the Slav nation.

Ključne besede: nacionalna zavest slovanskih narodov, zgodovina v obdobju romantike, romantična inačica »ogledala duše«, pridiga v 19. stoletju, moderna nacionalna identiteta, madžarska, češka/slovaška literatura $v$ 19. stoletju

Key words: National consciousness of the Slav nations, history in the Romantic Age, romantic version of the "mirror of the soul", sermon in the $19^{\text {th }}$ century, modern national identity, Hungarian and Czech/ Slovak literature in the $19^{\text {th }}$ century 
Jede Nation muss es fühlen lernen, dass sie nicht im Auge andrer, nicht im Munde der Nachwelt, sondern nur in sich, in sich selbst gross, schön, edel, reich, wohlgeordnet, tätig und glücklich werde und dass sodann die fremde wie die späte Achtung ihr wie der Schatte dem Körper folge. (Herder 1986: 268)

\section{Tudományosság és történetiség}

A romantikus történetiség az újkori európai kultúrtörténetnek abban a szakaszában fejlödött ki, amely a pozitivizmust közvetlenül megelözte. A romantikus történetiség ezért semmiképpen sem mérhető a pozitivista tudományosság mércéjével.

A pozitivizmus előtti és a pozitivizmus utáni történetiség különbözőségét leginkább azzal szemléltethetjük, ahogyan a pozitivista tudomány a romantikus történettudományhoz viszonyult. Az empirikus adatgyüjtés és logikus rendszerezés módszertani bástyái mögül a pozitivista történettudomány egyszerüen hamisnak minősítette a 19. század első felében a kreativitás és fantázia segítségével létrehozott történeti tényeket, alkotásokat. Nem jártak jobban megalkotóik sem, akiket a pozitivista tudomány egyszerủen kiiktatott a történeti hagyományból. Ily módon szorult a tudomány és a mủvészetek közötti senkiföldjére a romantikus történettudomány számos jeles képviselője, többek között Ján Kollár is. Kollár hatalmas történettudományi munkásságot hagyott maga után, és életpályáján előre haladva egyre nagyobb jelentőséget tulajdonított ilyen irányú tevékenységének. Ezzel a tudománytörténeti folyamattal magyarázható, hogy Kollár történelmi témájú munkái hosszú időre kikerültek a kutatók figyelmének középpontjából. Marginalizációjuk eredményeként (a szerző szándéka ellenére (a kollári mű helye is megváltozott a nemzeti kultúrában és tudományban.

Ugyanakkor számos jel mutat arra, hogy ezen alkotások jelentős része beépült a modern nemzeti kultúrába és tudatba, és hatása mindmáig érezhető és látható. Akárcsak azon csillagok fénye, amelyek olyan távolságban helyezkednek el bolygónktól, hogy fényüket még látjuk, bár a fényforrás talán már régesrégen kialudt. Egy ilyen ikercsillagot választottam e dolgozatomban a vizsgálat tárgyául, és megkísérlem rekonstruálni azokat a körülményeket, amelyek egykor hathattak ennek a páros égitestnek a keletkezésére. A szláv nemzet jó tulajdonságai címet viselő iker-prédikáció egyike a legnagyobb hatástörténettel rendelkezőknek a 19. század első felében. Jelentőségét nem lehet túlbecsülni a cseh és a szlovák emblematikus nemzetrajz romantikus fejlődésében, hiszen a nemzeti önismeret olyan darabjáról van szó, amely fontos szerepet játszott a nemzetről való gondolkodás fejlődésében.

\section{A szláv nemzet jó tulajdonságai prédikációk keletkezése}

A szláv nemzet jó tulajdonságai címü prédikációk elhangzásának pontos idejét Kollár az 1822-es év Szentháromság ünnepe utáni hatodik vasárnapjára, Péter 
Pál napjára datálta. Mindez a prédikációk második megjelenéséből világlik ki, amikor is Kollár beleszerkesztette őket 1831-es prédikációgyüjteményének az első kötetébe. „W den Petra a Pawla a w neděli ssestau po S. Trogici (1822)” (Kollár 1831). Az első megjelenés alkalmával az iker-prédikáció külön füzetben jelent meg huszonhat számozott oldalon (Kollár 1822), ám ez a kiadás az évszámon kívül nem tartalmaz pontosabb utalást az elhangzás időpontjára, ami nyilvánvalóan arra utal, hogy a két prédikáció az elhangzás évében még élénken élt a gyülekezet emlékezetében, ezért fölöslegesnek látszott ennek a ténynek a hangsúlyozása.

(Az első és második megjelenés szövege közötti különbségek első pillantásra nem haladják meg a helyesírási kérdéseket. Tüzetesebb összevetés során azonban adódik még néhány egyéb jellegű különbség, amelyekre e tanulmányban csak abban az esetben fogok kitérni, amennyiben az fontos a dolgozat tárgya szempontjából.)

A történetiség szempontjából lényeges, hogy milyen körülmények indították Kollárt arra, hogy a nemzet kérdését a szószékre vigye, és ezáltal a szakralitás dimenizióját kölcsönözze olyan világi jelenségnek, mint a nemzet. A világi témák megjelenése a szlovák evangélikus gyülekezetek istentiszteleti rendjében a prédikáció-történetnek számos korszakában megfigyelhetőek (Raffay 1944). Ján Kollár prédikátori tevékenysége ahhoz a korszakhoz kötődik, amelyet a felvilágosodáskori racionalizmuson belül is a gyakorlatiasság (prakticizmus) jellemez. Az ebbe a csoportba sorolható igehirdetők a tanításra helyezik prédikációik hangsúlyát. A legfontosabb kérdés a számukra, milyen hatást gyakorolnak a hallgatóságra, mennyire képesek pasztorációs céljaik szolgálatába állítani prédikációjukat. Ezért az Igéhez való viszonyuk többnyire praktikus jellegü és erkölcsi tanító célzatú. Számos esetben attól sem riadnak vissza, hogy az Igét alárendeljék az erkölcsi vagy más egyéb pasztorációs célnak (sőt, olykor erőszakosan hozzáidomítsák prédikációjuk világi, gyakorlati mondanivalójához (Michalko 1955: 44-102).

A pesti evangélikus gyülekezethez érkező Kollár rövidesen élére állt a szlovák hívek önállósulási törekvéseinek, amelyek a gyülekezeti életen belül érintették az önálló szlovák lelkész és a szlovák kántor státusát, a szlovák istentiszteletek rendjét és a szlovák iskolát (Matus 2000). Az önállósulási törekvések legfőbb akadályát az új német lelkész, Joseph Kalchbrenner, a német istentiszteletek túlsúlya és elsőbbsége, a német kántor túlterheltsége és a szlovák tanító-kántor és iskola hiánya jelentette. A 20-as évek elején tehát a szlovák nemzeti emancipációs törekvéseket a gyülekezeten belül elsősorban a szervezeti, anyagi és létszámbeli fölényben lévő német közösség korlátozta. Olyan időszak ez a magyar és a szlovák nemzeti ébredés időszakában, amikor a domináns némettel szemben, különösen, ha az az evangélikus egyház keretein belül zajlik, az érdekazonosság következtében kialakulhatott szövetség a szlovák és lélekszám tekintetében jóval kisebb magyar közösség között. Ennek a ténynek a leszögezése azért fontos, mert megvilágíthatja a magyar és szlovák együttműködés tényét, aminthogy a későbbi nemzeti küzdelmek, amelyek a magyarok túlsúlyát hozták, ugyanezen szövetség és együttmüködés későbbi elleplezését vagy nyílt megtagadását is eredményezhették. 


\section{A prédikáció keletkezésének immanens tényezői}

Visszakanyarodva Kollár prédikációihoz elmondhatjuk, hogy azok egyértelmüen apologetikus jellegüek - olyan vallási közösség és a vallási kereteken belül is megnyilvánuló nemzeti érdekek védelmére irányulnak, amelyet mind a korabeli jegyzőkönyvek tanúbizonysága (Matus 2000: 23). mind Kollár utólagos interpretációja szerint („A szlovákok, látván, hogy elhanyagolják őket a németekhez képest, akiket persze jobban elláttak, részesítettek az istentiszteletben, minden vallással és vallási fölkészüléssel szemben szinte hideggé és érdektelenné váltak.”) (Kollár 1831: III) azzal vádolnak, hogy közömbös a vallása iránt és elhanyagolja ilyen irányú kötelességeit. Nem csodálható tehát, ha a prédikátor költő a szláv nemzet első és legfontosabb jó tulajdonságának az ,istenességet” (,nábožnost”) tette meg. Ez a pesti evangélikus gyülekezet belső életéből fakadó fenomén kitüntetett helyet kapott Kollár prédikációjában. A hangsúlyos első hely egyben arra a tényre is utal, hogy az evangélikus egyházi élet olyan keretként is szolgált a 19. század első felében, amelyben a nemzettel kapcsolatos kérdések és a nemzeti küzdelmek is manifesztálódtak (Kertész 2007) (Kollár 1842).

A második szláv jó tulajdonságnak Kollár a „dolgosság”-ot láttatja. A dolgosság és szorgalom erényként való szerepeltetésének egyik lehetséges kézenfekvő magyarázatát a polgári fejlődés bizonyos fokához kötődő protestáns munkaerkölcs nyújtja. Eszerint a munkavégzés az imádság egyik fontos és lehetséges formája. Az imádságos és dolgos életből fakadó isteni áldást pedig már ószövetségi vonatkozásaiban is az anyagi javak bősége kísérte. A pesti evangélikus egyházközség esetében a gyülekezet vagyonosabb és tekintélyesebb részét a németajkúak alkották. Ezért a kevésbé tehetős és a társadalmi ranglétra alacsonyabb fokán álló szlovák hívek számára a kollári prédikáció második pontja, ha védelmet nem is jelentett az ilyen jellegü kritikával szemben a német gyülekezet részéről, (Matus 2000: 15-30) de legalább némi vigaszt nyújtott az elmérgesedő egyházközségen belüli vitákban.

A dolgosság mint erény megjelenése ugyanakkor a népiességhez is kapcsolódik azáltal, hogy a paraszti élet részét alkotó nehéz fizikai munkához kapcsolódó énekek és mesék a 19. század folyamán bekerültek a felvilágosodás kori magas nemzeti kultúrákba. A plebejusság mint fenomén ugyan egyre távolabb került Kollártól élete folyamán, ám mind népköltészeti gyüjtésében (Kollár 1831a: 277-318), mind pedig a következő erény, az ártatlan vidámság taglalása során előkelő helyet biztosított a legnehezebb fizikai munkát végző társadalmi osztály dolgosságának. A dolgosság szinonimájaként a szorgalom eröteljes hangsúlyt kapott J. G. Herder szláv népekkel kapcsolatos eszmefuttatásaiban is - Kollár ezzel a külső tényezővel erősítette meg a fenomén immanens jelenlétét a prédikációiban. A szakirodalomban meglehetősen eltérő nézetek találhatóak azzal kapcsolatban, milyen hatást gyakorolt Herder Kollárra. Rudo Brtáň tanulmányában tagadja a közvetlen hatást, és inkább a hazai irodalmi hagyományból származtatja a gondolatokat (Brtáň é. n.: 31 skk.). Elena Várossová ezzel szemben kézenfekvőnek tartja a herderi hatást (Várossová 1963: 42 
skk.). Herder a történelem kerekének forgandóságán morfondírozva úgy látja, hogy a háború szellemét fölváltó csöndes szorgalom beköszöntő korszaka meghozza a jobb jövőt Európa számára, a szláv népek pedig, amelyek egykor „szorgalmasak és boldogak” voltak, fölébrednek álmukból és megszabadulnak rabszolgaláncaiktól.

Das Rad der ändernden Zeit drehet sich indess unaushaltsam; und da diese Nationen gröstentheils den schönsten Erdstrich Europa's bewohnen, wenn er ganz bebauet und der Handel daraus eröfnet würde, da es auch wohl nicht anders zu denken ist, als das in Europa die Gesetzgebung und Politik statt des kriegerischen Geistes immer mehr den stillen Fleiss und das ruhige Verkehr der Völker unter einander befördern müssen und befördern werden, so werdet auch ihr so tief versunkene, einst fleissige und glückliche Völker endlich einmal von eurem langen trägen Schlaf ermuntert, von euren Sklavenketten befreiet, eure schönen Gegenden vom Adriatischen Meer bis zum karpathischen Gebirge, vom Dom bis zur Mulda als Eigenthum nutzen, und eure alten Feste des ruhigen Fleisses und Handels auf ihnen feiern dörfen (Herder 1792: 42).

A herderi gondolatmenet, amely összekapcsolja a szorgalmat és a boldogságot, elvezet a Kollár által harmadik helyen megnevezett szláv jó tulajdonság tárgyalásához, amelyet a prédikátor ,ártatlan vidámság”-nak nevezett el. Kollár az egész napos mezei munkáról hazatérő, vidáman daloló szláv parasztok képével egy ókori toposz modern szláv bukolikus változatát indította útjára.

A felvilágosodás és romantika korának természetesség-kultuszával és népiességével magyarázható a szlávok negyedik jó tulajdonsága, az „anyanyelv szeretete" is, amely a pesti szlovák evangélikusok esetében a húszas évek elején inkább hő óhaj, semmint realitás volt. A magyar királyság „Londonjába” (Horvát 1810: 25-26) mint gyorsan iparosodó nagyvárosba munka után érkező és megtelepedő szlovákok többségére sokkal inkább jellemző volt a nyelvi asszimilációs készség.

Ennek a hajlandóságnak a folyománya lehetett a „más nemzet iránti türelem” is mint ötödik szláv jótulajdonság. Az alacsony iskolázottságú, szakképzetlen vagy mesteremberként érkező észak-magyarországi szláv népesség alkotta elsősorban a pesti evangélikus szlovák gyülekezetet, amely a más nemzet (elsősorban a német) iránti türelem erényét kénytelen volt gyakorolni a pesti német őshonos polgársággal szemben. Amiért ez a tulajdonság mint erény mégis bekerült Kollár prédikációjába, az inkább annak a kifejeződése, hogy a Pesten új otthonra találó, számban és vagyonban gyarapodó szláv/szlovák közösség nevében prédikátoruk kifejezze azt a kívánságot és igényt, hogy a más nemzet iránti türelemnek kölcsönösnek kell lennie.

A szláv nemzet jó tulajdonságait (,vallásosság, dolgosság, ártatlan vidámság, az anyanyelv szeretete és a más nemzet iránti türelem” („Nábožnost, pracowitost, newinná weselost, milowánj swé řeči a snášeliwost naproti giným národům." /Kollár 1831: 6/) oly módon ismertettük, hogy közben igyekeztünk rámutatni azokra a forrásokra, amelyeket a szakirodalom lehetséges eredetükként jelölt meg. E tulajdonságok egy részének a bekerülése tehát a prédikációkba immanens módon következett a pesti evangélikus egyházközség életének többé-kevésbé ismert eseményeiből, amelyeket Kollár igyekezett a 
felvilágosodás racionalizmusának megfelelően magasabb eszmei síkon megfogalmazni. E tulajdonságok másik része ugyanakkor eredeztethető olyan külső impulzusokból is, amelyeket Kollár történelmi és filozófiai olvasmányaiból, elsősorban a felvilágosodás kori német filozófiából merített. (Matthias Murko feltételezése szerint Kollár pesti éveiben nyúlt Herder műveihez, és alaposan megismerkedett velük. /Murko 1897: 216. 1. jegyzet/) Harmadik lehetséges forrásként a 18. század végének és a 19. század első évtizedeinek német és szláv nyelvü történeti és földrajzi munkáit jelöli meg a szakirodalom, amelyek a nemzetkarakterológia tárgykörébe tartozó szövegeket is tartalmaztak. Így például a Staré noviny-ban (1785: 37) található Ján Hrdlička írást, amelyben a szerző kiemeli a szlávok bizonyos tulajdonságait (,úctivost', dobrotivost', milosrdnost', prívetivost' k host'om, štedrost', vl'údnost', pracovitost', usilovnost' a spôsobnost' literárnu i v učení sa jazykom" (Brtáň, é. n.: 8).

\section{A szláv nemzet jó tulajdonságainak magyarországi forrásvidékén}

A lelkipásztori szolgálatnak, amelyet Kollár majdnem harminc évig látott el Pesten, vannak és mindig is voltak olyan kényszerítő körülményei is, amelyekről a szakirodalom ezidáig kevéssé vett tudomást. Az evangélikus egyházközségek, amennyiben a történelmi körülmények engedték, pontosan szabályozták a lelkészi hivatalt betöltő prédikátor kötelességeit, többek között a heti rendes és rendkívüli prédikációk számát is. Az ezzel kapcsolatos szabályozások jól ismertek a magyarországi evangélikus egyház történetében (Michalko 1955: 18-19) mindazonáltal ezidáig nem tulajdonítottak ezeknek a tényeknek túl nagy jelentőséget Kollár müvészi életmüvének, az életmü keletkezésének a szempontjából. Ján Michalko prédikációs irányzatokat bemutató monográfiája nyomán a szlovák irodalomtörténészek közül néhány elálmodozott arról, hogy Kollár, mivel köztudomásúlag lelkiismeretesen igyekezett teljesíteni lelkipásztori kötelességeit, harminc éves pesti müködése során hány prédikációt tartott és vetett papírra (Michalko 1955: 70). Az impozáns számok büvöletében (mintegy száz kötetről lenne szó), az ezzel kapcsolatban megfogalmazott gondolatok közben azonban elsikkadt az a tény, hogy különösen a racionalista-gyakorlatias egyházi beszédek megírásához és megtartásához, amelyekbe nagyon sok nem biblikus jellegü tartalom is beszüremkedett, óriási mennyiségü világi és tudományos információra volt szükség. Ezt a hatalmas olvasmány- és müveltséganyagot Kollár a rendelkezésére álló valamennyi eszközzel igyekezett megszerezni. Levelezésének nagy részében találhatóak olyan kérések, amelyek könyvek és folyóiratok beszerzésére irányulnak. Ezek tetemes része német és szláv nyelvű munkákra vonatkozik, amelyek beszerzése időbeli korlátokba és egyéb nehézségekbe ütközött pesti környezetében. Ugyanakkor a magyar szlavisztika megkezdte azoknak a forrásoknak a föltárását is, amelyek Kollárnak a magyar kulturális élethez való viszonyát tárgyalják (Sziklay 1965: 139-175; Fried 1995: 133-136; Fried 2004: 51-68). Ezekből az írásokból, amelyek egyrészt személyes kapcsolataira, másrészt olvasmányélményeinek föltérképezésére irányulnak, 
egyértelműen kiderül, hogy pesti tartózkodásának évtizedei során az anyanyelvi és német müveltségi ismeretei mellé folyamatosan fölzárkóztak az egyre nagyobb számban megjelenő magyar irodalmi és tudományos kiadványok is.

Közéjük sorolható többek között a Tudományos Gyűjtemény címü folyóirat is. A Tudományos Gyüjtemény mintegy negyedszázadon át meghatározta a kialakulóban lévő modern közép-európai nemzetekről való gondolkozást. Hatása ezért nemcsak a magyar, hanem más nemzetiségü értelmiségi körökben is mérvadónak nevezhető. Kulcsfontosságú voltára a szlovák szellemi életben legújabban Peter Macho mutatott rá tanulmányában, amelyben érintette többek között Kollár és a lap kapcsolatát is (Macho 2006: 110-124).

Ennek a folyóiratnak az 1817-es évfolyamában látott napvilágot Horváth János veszprémi kanonoknak (1769-1835) egy olyan tanulmánya, amely a kollári prédikációk genezisének a szempontjából is figyelmet érdemel. $A$ ' régi Magyaroknak Vallásbéli 's Erkölcsi Állapottyokról címü tanulmány (Horváth 1817: I. 27-66, II. 67-91) egymást követő két részben, hatvannégy oldalon keresztül taglalja a régi magyarok vallási és erkölcsi szokásait, tulajdonságait. Horváth János tíz pontba rendezte a témával kapcsolatos gondolatait. Az első fejezetben általános vallástörténeti szempontból közeledik a problémához, amelynek keretében a hit és a poézis viszonyát vizsgálva megállapítja, hogy a költészet, ameddig a hit szolgálatában áll, helyénvaló, míg ha önálló utakra tér, annak következménye az elvallástalanodás. A hit megőrzésének legfőbb példájául a zsidókat nevezi meg, akik hosszú történelmük során a leginkább megőrizték eredeti vallásosságukat. (Kollár 1829) Ugyanez a motívum Kollárnál is megtalálható egyrészt a textus kiválasztásában (1Mózes 12. V. 1-2.) tükröződik, másrészt a zsidó bölcsekre való hivatkozásban, akiket Horváth is említ. Horváth a hit és az ész viszonyát elemezve arra a megállapításra jut, hogy a racionalizmus magasabb szinten meghaladja önmaga vallásellenességet. Az okfejtés kapcsán Horváth tanúbizonyságát adja filozófiai müveltségének, hiszen a német romantikus történelemfilozófia egyik fontos terminusát, a Weltgeist-et magyarítja ,a' Világ lelke”-ként (Horváth 1817: I. 50). A horváthi gondolatmenet meglehetősen nagy ívü, hiszen az ősvallással kezdődik és egészen az újkori nihilizmusig terjed. Az első fejezet utolsó gondolata, amelyben Horváth annak a nézetének ad hangot, hogy a más népekkel való közösködés is hátrányosan befolyásolhatja egy nemzet valláshoz való viszonyát, szintén utat talált Kollár prédikációjába. Horváth azt írja, hogy a történelem folyamán „a' babonás vagy istentelen népekkel való öszve elegyedés 's közösülés is, sokakban megrongálta, elcsufította a' tisztább isméreteket [a vallásról] (Horváth 1817: I. 51). Kollárnál ez a gondolat ugyanebben az értelemben jelenik meg: „sőt azt sem titkolom, hogy természetesen e nemzetben is található sok rossz keresztyén, nemtörődöm, hideg, istentelen, különösen ott, ahol már másokkal szomszédságba és kapcsolatba keveredtek” (,ba y to nezatagjm, že se wšem y w tomto národu nalezegj mnozý zlj křest’ané, nedbanliwj, studenj, bezbožnj, obzwláště tam, kde již s ginými do sausedstwj a spogenj přišli” (Kollár 1822: 7). A horváthi hosszadalmas vallásról szóló bölcselkedés további része mind- 
azonáltal a fölvetett témát csak variálja, ezért Kollár számára nem tartalmazott további különösebb kamatoztatnivaló gondolatot.

Sokkal inkább fölkeltette érdeklődését a tanulmány második része, amely A' Magyaroknak Istenröl való isméretök címet viseli. Ez a fejezet abból a szempontból érdemel figyelmet, hogy benne Horváth hosszas magyarázattal szolgál a magyar Isten szó eredetével kapcsolatban. Az etimológiai kalandozás során Horváth sorra veszi a magyar őstörténet idejében virágzó jelentős kultúrákat, és lehetséges perzsa, egyiptomi, ógörög, héber etimológiákkal áll elő. A magyar szerzővel Kollár mint szláv literátus-etimológus régiségi versenybe száll. Kollár, nem akarván alulmaradni a küzdelemben, a vallásos dolgok megnevezésének szláv nyelvben megtalálható gazdagságára irányítja hívei figyelmét, és Horváthtal szemben azt hangsúlyozza, hogy a szláv nemzet nagy mennyiségben alkotott saját szavakat és kifejezéseket a vallásos élet dolgainak megnevezésére: ,aligha rendelkezik más egyéb nemzet a szavaknak olyan gazdagságával a saját nyelvében, amelyekkel megnevezhetné a szent dolgokat mint pl. vallás, szentség, tempom és sok egyéb” - „sotwy ktorý giný národ má takowau hognost wlastnjch slow we swé řeči kterýmiby swaté wěcy poznamenal k. p. náboženstwj, swátost, chrám, a mnohé giné” (Kollár 1822: 6). A prédikáció mint müfaj azonban nemigen visel el több filológiai példát, így Kollár újból figyelmen kívül hagyja Horváth több tucat oldalon keresztül tartó fejtegetéseit az ősmagyarok lélekkel, áldozással, táltosokkal, ünnepeikkel, házassági és temetkezési szokásaival kapcsolatban. Helyette figyelmét a tanulmányban inkább az a rész kötötte le, amelyben a magyar szerző megkezdi a magyarok erkölcsi állapotának tárgyalását. Horváth János a második részt tíz fejezetre tagolta, amelyek a következő címeket viselik:

$\S 1$. Az ö értelmökben a' jó és rosz

$\S 2$. A' vitézség vala a' fó virtus

$\S 3$. Az istenesség

$\S 4$. 'S igasság az ő gondolkozások szerént

$\S 5$. Házi érzeménnyeik

$\S$ 6. Tisztaság szeretetök

$\S 7$. Vendégeskedéseik 's mulatságaik

§ 8. Más nemzettségbeliekkel való bánások’ módgya

$\S 9$. Kevélységök

§ 10. Pénzre vágyások, 's elvadulások

Miként az a fejezetcímekből nyilvánvalóan kiderül, Horváth János tanulmányának esetében a vallási irodalomból ismert lelki tükör mint müfaj egyfajta újkori alkalmazásáról és újraértelmezéséről van szó, amely a reformkor szellemének megfelelően vizsgálat alá veszi a nemzeti erényeket és hibákat. A nemzeti lelkiismeret-vizsgálat célja megegyezik a keresztény lelkiismeretvizsgálatéval. A lelkiismeretvizsgálat szakrális célja az istenszeretetben való tökéletesedés, amely az üdvözülés feltételét jelenti. A 19. század elejének nemzettel kapcsolatos gondolkodásmódja a lelkiismeret-vizsgálatnak ezt a formáját 
szekularizálta. A nemzetszeretetet állította a vizsgálat középpontjába, és a nemzeti iránti elkötelezettség jegyében kreálta meg, gyakran retrospektív módon, a nemzet történelmi múltját is. Ugyanakkor a nemzeti történelem tanulsága a jelen nemzedékének szolgál példával, és annak jövőbeni boldogulását célozza.

Mivel azonban a történelmi Magyarország nemzetei, a magyar és a szláv/ szlovák a nemzeti és társadalmi fejlődés más-más szintjén állt ebben az időszakban, ezért a nemzeti lelkitükrök is eltérö sajátosságokat mutatnak. A horváthi magyar nemzeti lelki tükör a jó és rossz tulajdonságok kiegyensúlyozott arányával tünik ki. Nemcsak hogy a jó és a rossz nemzeti tulajdonságok kiegyenlített arányban vannak jelen, hanem minden tulajdonság esetében megfigyelhető egyfajta történeti viszonyulás a tárgyalt jelenséghez. Kollár prédikációjának magyar elöképéről tanúskodik többek között a szláv prédikátornak az az elszólása is a mű bevezető szakaszában, amelyben azt vetíti előre, hogy - Horváthhoz hasonlóan (ő is hiteles képet akar festeni a szláv nemzet jó és rossz tulajdonságairól: „Tak weliký, tak starožitný, slawný a pamatný národ dozagista zaslaužj aby sme geho žiwot, powahu a wlastnosti y před trůn náboženstwj postawili, a sprawedliwě ohlédali y co dobrého y co chybného při sobě má abychom znali gakowými prowinnostmi y my k němu zawázání gsme.” A görbe tükör azonban, amelyben megmutatkoznának a szlávok rossz tulajdonságai is, kiegyenesedik és megfényesedik, és a szerzői ígéret ellenére csupán a szláv erények tünnek elő bennük.

A horváthi lelki tükör további sajátossága, hogy egy több száz éves rendi államiság morális és vallási örökségét kísérli meg az alakulófélben lévő modern nemzeti keretek között értelmezni. A kollári nemzeti tükör ezzel szemben a magyar államiság jelenlétének hiányával tűnik ki, amely megelőlegez egyfajta nemzeti kivonulást ezen államiság keretei közül (Kiss Szemán 2007: 5-32). A kivonulást az tette szükségessé, hogy a bomlófélben lévő rendi államiság keretei szüknek bizonyultak valamennyi magyarországi modern nemzet számára. A berendezkedő modern magyar nemzet ugyanis sajátján kívül nem ismert el más nemzeti jogokat. Költözéskor pedig általában az ember csak azt viszi magával, ami a legfontosabb számára. A magyarországi szlávok úti batyujából azért volt teljes mértékben kihagyható a vitézség erénye, mert az elsősorban a magyar királyság évszázados továbbélését volt hivatva biztosítani a történelmi viharokban, s mint ilyet, kontinuusnak csupán a modern magyar nemzeti tudat építette magába. Az így támadt ürt azonban, amely az erények csomagjában a magyar vitézség virtusának kiesésével keletkezett, Kollár a „szorgalmas dolgosság” mint szláv jó tulajdonsághoz tartozó békeszeretetének hangsúlyozásával ellenpontozta: „Gsauce dle přirozenj swého wětsj milownjcy pokoge nežli bogowánj" (Kollár 1822: 8).

Horváth tanulmányában a magyarok vitézségének bemutatása után az istenesség tárgyalása következik. A veszprémi kanonok az istenességet alapvetően vallástörténeti szempontból közelítette meg. Ennek a történeti nézőpontnak az az eredménye, hogy a szerző az ősmagyarok istenességét már az ősmagyar történelem során is történetiségében differenciáltan jeleníti meg. Horváth szerint a kezdeti idilli állapotot, amely a nemzetek geneziséhez köthető, amely során 
minden nemzet egyenlő mértékben részesült az isteni kegyelem ajándékából, a magyarok esetében a későbbi nemzedékek vallásos elhidegülése követi. A nemzedéki hanyatlás okát a szerző látszólag a hidegebb baskíriai éghajlatban jelöli meg („Onokáikban ellenben már meghűle Baskirban a’ fagyos éghajlat alatt az istenes buzgóság, a régi Cultusok nyomorúlt Samanizmussá változván.” (Horváth 1817: 70), valójában azonban annak az ókor óta jól ismert vallástörténeti toposznak az alkalmazásáról van szó, amely a történelmet és az emberi nemet hanyatló tendenciájában mutatja be.

Horváth a negyedik fejezetben pendíti meg a más nemzetségbeliekhez, más népekhez való viszony témáját. E tekintetben leszögezi, hogy a magyar csak a saját nemzetségbeliekhez való viszonyában követte az igazságosság elvárását, az idegen népekkel szemben nem: „miképpen más nyers népeknek önnön csoportyok szűk korláttyain túl nem egykönnyen terjednek ki társaságos érzeményeik, 's e' szavaknak: idegen és ellenség nálok ugyanazon értelmök vagyon (...) az idegeneknek személlyekre, javaikra, gyermekeikre nézve pedig azt tartották, a' ki győzi, az bírja" (Horváth 1817: 73).

A hatodik, rövid fejezet a magyarok tisztaságszeretetéröl szól, amely nem a test, hanem a lélek erkölcsi tisztaságát és tartózkodását jelentette. Ebben az értelemben használja a tisztaság mint erény fogalmát Kollár is az első prédikáció záró bekezdésében. Ez az a klauzula vagy összefoglaló rész, amelynek legfontosabb mondanivalója, hogy a szláv nemzet a tárgyalt erényeken kívül természetesen még számos egyéb jó tulajdonsággal is rendelkezik, amelyekröl hely és idő hiányában a prédikátornak csak rövid formában adatik meg szólni. A kollári fölsorolásban a szláv nemzet tisztasága (čistota) közvetlenül a szemérmesség (stud) erénye után szerepel, amely egyértelművé teszi, hogy Kollár azonos erkölcsi értelemben használja a fogalmat, mint a magyar szerző. Hasonlóképpen a tisztasághoz a prédikáció végén fölsorolt egyéb erények sorában megjelenik még a háziasság (domácnost) is, amely Horváthnál a házi érzeményekről szóló 5. fejezet egyik fö motívuma, valamint a vendégbarátság (pohostinství), amely Horváth János tanulmányának most következő 7. fejezetében kapott hangsúlyos helyet.

Ez a rész a magyarok vendégeskedéseit és mulatságait írja le. A szerző a honfoglalás eseményeihez kötődő duhaj mulatságokról ír: „Árpád pedig és az ő Fő emberei gyözödelmelkről (sic!) tudatosítatván egész héten nagy pompáson, és vígan ettek, és ittak, és majd nem minden nap megrészegedtek, ennek a nagy örömnek a megtörténéséért.” (Horváth 1817: 79) Horváth „a’ részegeskedésre való hajlandóságot" (Horváth 1817: 81) történelmi örökségnek tartja, és föként a magasabb társadalmi osztályhoz köti. A mulatságok természetes részének tartották a többféle fajta táncot is. Kollár az effajta dionüszoszi mulatság szokását ellentétesnek tartja a protestáns puritanizmussal. A szláv nemzet jó tulajdonságai közé a vigasságnak puritán, „,büntelen” változatát emelte be az „ártatlan vidámság” erényével:

Bizony ki merészelne szigorú arccal morgolódni az ilyen vidámság ellen, amely se nem zabolátlanság, se nem dorbézolás, hanem az egészséges és tiszta sziv jele? Az öröm is szülöanyja lehet az erénynek, az lágyítja meg legjobban a kemény embert, szelíditi meg 
legkönnyebben a vadat, a kegyetlent legbiztosabban hajlitja kegyességre és szeretetre, az öröm megkönnyit minden munkát, enyhíti a nehéz bánatot, és kellemesebben vezet az Istenhez és az éghez mint a szigorú, néma, szomorú élet vagy az állanó sírás, sopánkodás és kétségbeesés.

A kdo by směl s přjsnau twářj reptati proti takovéto weselosti, která nenj rozpustilost ani prostopášnost, ale znamenj zdrawého a čistého srdce? I radost zajisté může býti matka a půwodkyně cnosti, ona twrdého člowěka neylépe obměkčuge, diwého neysnadněgi krotj, nemilosrdného neygistěgi k milosrdenstwj a k lásce nakloňuge, ona každau prácy polehčuge, t’ažkau žalost mjrnj, a přjgemněgi k Bohu a k nebi wede nežli přjsné, němé, smutné žiwobytj anebo ustawičný pláč, skuhráni a zaufánj (Kollár, 1822: 10).

Horváth János tanulmányának 8. fejezetében az idegen nemzetségekkel és nemzetekkel való bánásmód változását mutatja be. Elrugaszkodási pontul ismét a magyar őstörténet szolgál, amelyet Anonymus krónikája alapján elevenít fel: „Régi dicséret Eleinknek Öseikről, hogy a’ Szittyai nép igen bölcs és szeléd volt légyen" (Horváth 1817: 84). Ám míg Baskíriában békésen éltek együtt számos más néppel, a honfoglalás idejére erényeik igencsak megfogyatkoztanak. Az őstörténetet megelevenítő lelki tükörben tehát egyrészt megjelennek az erkölcsi fogyatkozásban szenvedő honfoglaláskori ómagyarok, és megpillanthatják magukat a kortárs magyarok is. Horváth ősmúltat (ősmagyarok vándorlása) és régmúltat (ómagyarok honfoglalása) szembeállító gondolkodásmódjával ellentétben Kollár prédikációjában csupán a jelen állapotát rögzíti. A most szolgál számára kiindulópontul a jövő számára is. Ilyen fajta történetiség Kollár prédikációjában nem jelenik meg. Kollár számára a szláv történelem ekkor még nem rétegződik régmúlt és múlt korokra: toposza szerint a szláv nemzet természetéből fakadó szelídsége állandó tényező, amely mit sem változott a történelem folyamán.

A prédikációk olyannyira gyakorlatias célokat szolgálva szóltak a jelenhez, hogy azok első, 1822-es kiadásához Kollár még nem készített történeti tárgyú hivatkozásokat. A szláv népek elszenvedett sanyargattatásaival kapcsolatos jegyzetek, amelyekben Gebhardira, Lützowra, Karamzinra és Weselyre hivatkozik, csupán az 1831-es Kázně kiadásába kerültek bele. Ezek közül az utolsóban Eugen Wesely: Serbische Hochzeitslieder-jére utalva (Pest, 1826) a szerbek hősi harcait is csupán önvédelminek minősíti (Kollár 1831: 235). (A jegyzetek megjelenésének ténye kilenc évvel a prédikációk megírása után azt a másutt megfogalmazott feltevésünket támasztja alá, hogy Kollár tudatos filológiai munkával igyekezett eltüntetni bizonyos nyomokat, amelyek a prédikációk keletkezésének magyar forrásaihoz vezettek volna.) Kollár ebben a müvében bocsátja szárnyára a nagy történelmi utat megtett „galambnemzet” toposzát (Kollár 1822: 13) is, amely egyik alappillérévé vált a 19. század első felében kikristályosodó cseh és a szlovák emblematikus nemzetrajznak (Kiss Szemán 2005).

Horváth János szomorúan állapítja meg, hogy a magyarok „Későbben (...) vadabbakká lettek, mintsem Baskirból jöttek volt; 's a' külföldiek eránt minden igasságérzésök elaludt, 's minden emberségből kivetkőztek" (Horváth 1817: 87). 
A veszprémi kanonok a fenti hangnemben folytatja az ómagyarok ostorozását az utolsó két fejezetben is. A megfogalmazott kritika a magyarok kevélységét veszi célba, amely a honfoglalás sikere során erősödött meg a főurakban, és vált a későbbiek során a nemzet egészének rossz tulajdonságává, melynek következménye, hogy magukat más magyarországi nemzet fölé helyezik (Horváth 1817: 88). A kollári nemzetkoncepció ennek a magyar nemzetképnek az ellenében fogalmazódott meg. Kollár iker-prédikációjában a más nemzetek iránt tanúsított türelem a legékesebb szláv jó tulajdonságok közé tartozik. Kollár prédikációjában is utal a Horváth által megidézett ismert magyar történelmi eseményekre. Szerinte míg más nemzetek a harcaikkal és háborúikkal büszkélkednek, a szlávok csendességükkel és szelídségükkel megbékítik őket.

Horváth János szerint a honfoglalást kísérő erkölcsi hanyatlás folytatódott a későbbi évszázadban is. Az ország meghódoltatása után a más nemzet iránt tanúsított türelmetlenséghez további bünök társultak, mint például a gazdagság utáni vágy. A magyarok hódolatra és pénzre vágyásuk további következményének tekintette a kalandozások korát, amely csak pusztulást és kínt hozott Európára. Horváth magyar történelmi lelki tükre ezzel a végkicsengését tekintve meglehetősen borús eseménysorozattal zárult. Mindazonáltal Horváth János lelki tükre, a magyar történelem további eseményeinek ismeretében és papi hivatása tudatában, más összefüggésben értelmezendő. Az ősmagyarok erkölcsi hanyatlása az eredeti ősvallás jó erkölcseitől való eltávolodás következménye, ugyanakkor azonban a hanyatlás az új erkölcsi fölemelkedés előfeltétele, amelyre már a kereszténység jegyében került sor.

Mint a fönti párhuzamokból kiviláglik, Kollár A szláv nemzet jó tulajdonságai címü iker-prédikációját a pesti evangélikus gyülekezet belső történetéből merítve annak szükségleteihez igazította. Ehhez rendelte hozzá történelemfilozófiai olvasmányaiból fakadó, elsősorban Herder munkáira építő ismereteit. Horváth János tanulmánya egyrészt ihlető erejével hatott az iker-prédikáció megszületésére, másrészt a jó és rossz tulajdonságok alapos számbavételével, műveltséganyagával olyan forrást jelentett számára, amelyből szerzői szándéka szerint meríthetett vagy elhagyhatott. Mindenesetre abszolút kreatív módon viszonyulva a fent nevezett forrásokhoz saját, önálló müvet alkotott, amelyet mủvészi és tudósi pályafutása során továbbfejlesztett, és amely szervesen beépült a közép-európai modern szláv nemzetek történelmébe és kultúrájába.

\section{IRODALOM}

Rudo BRTÁŇ, é.n.: Vznik, vývin a verzie Kollárovej rozpravy o literárnej vzájomnosti. Štúdia (S faksimile, autografom a 5 prílohami). Vydal Tranoscius v Liptovskom Sv. Mikuláši.

István FRIED, 1995: Ján Kollár és a magyar irodalom. Gál, Evžen, Berkes Tamás, Kolmanová, Simona (szerk.): K sedmdesátinám Petra Rákose. Rákos Péter hetvene- 
dik születésnapjára. Slavica Pragensia XXXVII. Ab imo pectore. Praha: Univerzita Karlova, Vydavatelství Karolinum.

- -, 2004: Ján Kollár és a magyar irodalom. Uő: A névadás lehetségessége. (Nemzetiség, régió, Európa). Pozsony/Bratislava: Madách-Posonium.

Johann Gottfried HERDER, 1792: Ideen zur Philosphie der Geschichte der Menscheit von Johann Gottfried Herder. Vierter Theil. Riga und Leipzig bei Johann Friedrich Hartknoch.

Johann Gottfried HERDER, 1986: Briefe zur Beförderung der Humanität. Vierte Gesinnung. Geläuterter Patriotismus. Herder. Ein Lesebuch für unsere Zeit. Berlin und Weimar: Augbau-Verlag.

István HORVÁT, 1810: Pest szabad királyi városnak régi Ofen német nevéröl. Pesten: Trattner Mátyás Betüivel.

János HORVÁTH, 1817: A' régi Magyaroknak Vallásbéli 's Erkölcsi Állapottyokról. A' magyar Anyaszentegyház' Történeteinek Próbájából. Első Rész. A' Régi Magyaroknak Vallásbéli Állapottyok. Tudományos Gyüjtemény 1817: II. kötet 27-66. Második Rész. Erkölcsi állapottyok. 67-91.

Botond KERTÉSZ, 2007: Evangélium és szabadság. Az evangélikus egyház Magyarországon 1848-49-ben. Budapest: a Magyar Protestáns Közmüvelődési Egyesület kiadványai 5. Societas et ecclesia.

Róbert KISS SZEMÁN, 2005: Ján Kollár, velký kreator. Grundlage II. Emblematický národopis: zeměpis, národopis, př́rodopis a zoologie. Slovanský prehled 4/2005. 557-563.

- -, 2007: Magyarország panaszától Szlávia panaszáig. Magyarország panaszától Szlávia panaszáig. Irodalmi tanulmányok. Budapest: ELTE Szláv Filológiai Tanszék.

Ján KOLLÁR, 1822: Dobré wlastnosti Národu Slowanského. Dwoge kázanj od Jana Kollára, Kazatele cjrkwe ewangel. Peštansko-Budjnské. W Pešti, pjsmem Jana Tomáše Trattnera z Petroce.

--, 1829: Proč se Bůh Syna swému a Spasiteli světa práwě mezi židovským národem naroditi dal. Wánočnj kázánj w druhau Slawnost roku 1829. od Jana Kollára. Wydané od posluchačů. W Pešti u P. J. M. Trattnera a Št. Károliho.

- -, 1831: Nedělní, svátečné i př́ležitostné Kázně a Řeči od Jana Kollára, cjrkwe ewangelické Peštansko-Budjnské sl. b. K. učené Společnosti krakowské úda. W Pešti, tiskem Trattnera a Karoliho.

--, 1831a: Národnié Zpiewanky čili Pjsně swětské Slowáků w Uhrách gak pospolitého lidu tak $i$ wyššjch stawü, sebrané od mnohých, w pořádek uwedené, wyswètlenimi opatřené a wydané od Jana Kollára. Djl perwý. Wydánj hogné rozmnožené i perwé dwa tištěné swazečky w sobě obsahugjcj. W Budjně w Král. Universické tiskárně.

--, 1842: Kollár levele (1842, július 19.) Jozeffy Pálhoz Szlovák Nemzeti Könyvtár Irodalmi és Művészeti Levéltár - Slovenská národná knižnica Archív literatúry a umenia M23 L30/2.

Peter MACHO, 2006: Poznámky k charakteru slovanských materiálov v mad’arskej predrevolučnej tlači (na príklade „Tudományos Gyüjtemény”). Ján Kollár a slovanská vzájomnost'. Genéza nacionalizmu v Strednej Európe. Szerk. Tatiana Ivantyšinová. 
Slovanské štúdie. Zvláštne číslo 4. Vydáva Spoločnost' pre dejiny a kultúru strednej a východnej Európy a Historický Ústav SAV.

Matthias MURKO, 1897: Deutsche Einflüsse auf die Anfänge der böhmischen Romantik. Mit einem Anhang: Kollár in Jena und beim Wartburgfest. Graz: VerlagsBuchhandlung „Styria”.

László MATUS, 2000: A Pesti Szlovák Evangélikus Gyülekezet. Piliscsaba: Pázmány Péter Katolikus Egyetem, Bölcsészettudományi Kar, szakdolgozat, történelem szak.

Ján MICHALKO, 1955: Kázňové smery. Vydal Tranoscius, Lipt. Mikuláš v cirkevnom nakladatel'stve Bratislava.

Sándor RAFFAY, 1944: Az evangélikus egyház liturgiája. Evangélikus templomok. Készült az Országos Luther Szövetség munkaközösségében Kemény Lajos a szerkesztőbizottság elnöke Dr. Gyimesy Károly felelős szerkesztő vezetésével. Budapest: Atheneum, 473-478.

László SZIKLAY, 1965: Ján Kollár magyar kapcsolatai Pesten. Tanulmányok a csehszlovák-magyar irodalmi kapcsolatok köréböl. Budapest: Akadémiai Kiadó.

Elena VÁROSSOVÁ, 1963: Slovenské obrodenecké myslenie. Jeho zdroje a základné idey. Bratislava: Vydavatel'stvo Slovenskej akadémie vied.

\section{JÁN KOLLÁR OZIROMA DOBRE LASTNOSTI SLOVANSKEGA NARODA?}

Študija opozarja na metodološke in nazorske razlike zgodovinske vede pred in po pozitivizmu ter poudarja, da se smejo Kollárjeva zgodovinska dela presojati le na podlagi metodologije romantične zgodovinske vede, v kateri je pomembno vlogo igrala tudi umetniška kreativnost. Med romantična dela sodi tudi Kollárjeva parna pridiga z naslovom Dobre lastnosti slovanskega naroda (prva objava leta 1822, druga leta 1831), ki je v veliki meri vplivala na narodno zavest sodobnih slovanskih narodov.

Glavni razlog za nastanek pridig je bil ta, da je v peštanski evangeličanski skupnosti nastal resen nesporazum med dominantnejšo, petičnejšo nemško skupnostjo in revnejšo slovaško skupnostjo, ki se je borila za enakopravnost. Pridigi imata prav zaradi tega apologetičen značaj, njun namen je zaščita slovaškega/slovanskega naroda. Kollár v njiju obravnava pet dobrih lastnosti slovanskega naroda: pobožnost, delavnost, nedolžno prešernost, ljubezen do maternega jezika in strpnost do drugih narodov. (Med temi lastnostmi se v določenem obdobju številne pojavljajo bolj kot želja in ne kot realnost.) Med možne vzorce teh dveh pridig sodi prispevek Jánosa Horvátha, kanonika $\mathrm{v}$ Veszprému, z naslovom $O$ verskem in moralnem stanju starih Madžarov, ki je izšel leta 1817 v Tudományos Gyüjteményu. Kollár je namreč v Pešti leta 1819 začel tridesetletno dušnopastirsko službo. Sam je bral in citiral v listu objavljene članke ter polemiziral z avtorji. Horváth je v svoji študiji, ki je bila bistveno obsežnejša kot Kollárjeva, v desetih točkah zbral lastnosti Madžarov, ki vsebujejo tudi kreposti in napake starih Madžarov:

$\S 1$. Dobro in zlo v njihovem razumevanju

$\S 2$. Glavno junaštvo je viteštvo

$\S 3$. Pobožnost

$\S$ 4. Pravica po njihovem razmišljanju 
§ 5. Domača občutenja

$\S 6$. Čistoča

$\S 7$. Gostovanja in zabave

$\S 8$. Način ravnanja $\mathrm{z}$ drugimi narodi

$\S 9$. Oholost

$\S 10$. Želja po denarju, podivjanost.

Žanr Horváthovega dela je posodobljena oblika „duhovnega ogledala”, znanega iz verske literature, ki se ujema s procesom sekularizacije. Zgodovinsko duhovno ogledalo za madžarske nacionalne namene je spodbujalo oblikovanje sodobne nacionalne identite. Kollár je iz Horváthove študije pustil Madžarom lastnost viteštva, povezano z obrambo madžarske državnosti (§ 2.), in slabe lastnosti (§ 9., § 10.), hkrati pa je elemente razmišljanja in velik del kreposti prevzel v svoji pridigi (§ 3.-8.). Prevzem zdaleč ni le zgolj prepis, ampak je kreativna umetniška dejavnost, s pomočjo katere je Kollár te misli v določeni meri prikrojil in prilagodil slovanskemu narodu. 